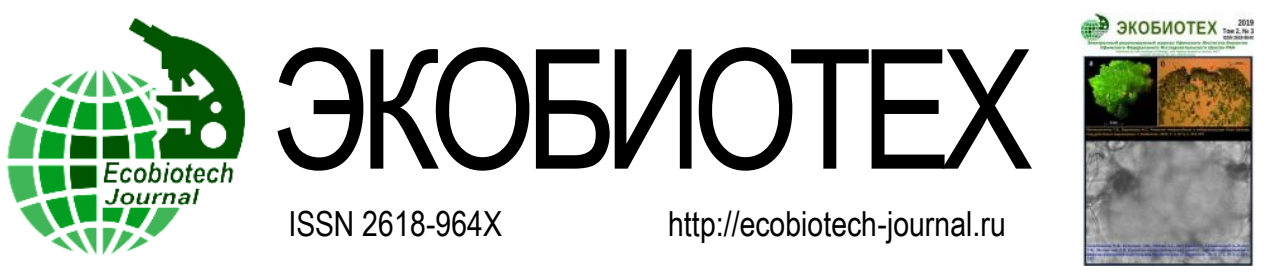

\section{РОЛЬ СУРФАКТИНА ЭНДОФИТНЫХ БАКТЕРИЙ \\ BACILLUS SUBTILIS 26Д В РАЗВИТИИ \\ СИМБИОТИЧЕСКИХ ОТНОШЕНИЙ С РАСТЕНИЯМИ КАРТОФЕЛЯ}

Сорокань А.В., Искандарова 3.Ф., Благова Д.К., Сарварова Е.В., Максимов И.В.

Институт биохимии и генетики Уфимского федерального исследовательского центра РАН, Уфра

E-mail: fourtyanns@googlemail.com

Большой интерес представляет взаимодействие растений с эндофитными бактериями. На основе исследования двух рекомбинантных штаммов на основе B. subtilis 26Д, в которых нарушен синтез липопептида сурфактина, показано, что высокая эффективность колонизации внутренних тканей растений картофеля исходным штаммом обусловлена отсутствием окислительного взрыва в инокулированных растениях.

Ключевые слова: Bacillus subtilis, сурфактин, эндофиты, АФК

\section{THE ROLE OF SURFACTINE PRODUCED BY ENDOPHITIC BACTERIA BACILLUS SUBTILIS 26D IN THE DEVELOPMENT OF SYMBIOTIC RELATIONS WITH POTATO PLANTS}

Sorokan A.V., Iskandarova Z.F., Blagova D.K., Sarvarova E.V., Maximov I.V.

Institute of Biochemistry and Genetics of the Ufa Federal Research Centre of the Russian Academy of Sciences, Ufa E-mail: fourtyanns@googlemail.com

The interaction of plants with endophytic bacteria is of great interest. Based on the study of two recombinant strains based on B. subtilis 26D, in which the synthesis of surfactin lipopeptide was disturbed, it was shown that the high efficiency of colonization of the internal tissues of potato plants by the surfactin-producing strain $B$. subtilis $26 \mathrm{D}$ is due to the absence of an oxidative burst in inoculated plants.

Keywords: Bacillus subtilis, surfactin, endophytes, ROS Поступила в редакиию: 8.07.2019

DOI: $10.31163 / 2618-964 X-2019-2-3-257-261$

\title{
ВВЕДЕНИЕ
}

Современное высокоэффективное сельскохозяйственное производство невозможно без применения удобрений и средств защиты растений. Эндофитными называются бактерии, способные колонизировать внутренние ткани растения, не вызывая его заболеваний и не оказывая отрицательного влияния на развитие. Бактериальные эндофиты колонизируют те же экологические ниши, что и фитопатогенные микроорганизмы, поэтому рассматриваются как перспективный агент биоконтроля фитопатогенов. Так, эндофитные симбионты растений могут вызвать определенные физиологические реакции в растительном организме, которые приводят к усилению резистентности растения к действию фитопатогенов. Это явление носит название индуцированной системной устойчивости - ISR (induced systemic resistance). Индуцируемая устойчивость не связана с прямой активацией биосинтеза защитных белков, но с феноменом, называемым защитным праймированием [Martinez-Medina et al., 2016].

Благодаря широкому кругу хозяев, способности формировать эндоспоры и продуцировать различные антибиотики вид Bacillus subtilis используется в качестве агента биоконтроля, поскольку обладает супрессивными качествами по отношению к широкому кругу фитопатогенов благодаря способности продуцировать множество вторичных метаболитов различной химической природы: циклических липопептидов, полипептидов, белков и непептидных соединений [Сидорова и др., 2018, Spaepen 2007]. Однако, не смотря на множество прикладных исследований эндофитных микроорганизмов, фундаментальные основы взаимодействия растения-хозяина и его микробиома остаются малоизученными. 
Вторичные метаболиты бактериальных микросимбионтов, такие как триптамин, которые могут служить в качестве гормонов или сигнальных молекул для «контроля» физиологии и поведения хозяина, также известны для растений [Galligan et al., 2018]. 74\% транскрипционных изменений, вызванных ризосферным штаммом Pseudomonas simiae WCS417, или его флагеллином, были связаны с подавлением инициируемых MAMPs патогенных микроорганизмов транскрипционных ответов, возможно, для обеспечения взаимовыгодного взаимодействия с корнем хозяина. Интересно, что сектор транскрипционной сети, репрессированной флагеллином, связан с сигналлингом ауксина [Stringlis et al., 2018]. Антимикробные соединения, такие как бактериоцины, сидерофоры и липидопептидные биосурфактанты, особенно характерные для бактерий рода Bacillus, позволяют вытеснять и уничтожать патогенные микроорганизмы и формировать структуру микробиоты, также влияя на иммунитет хозяина [Gozvami, Deka, 2019].

Tanaka et al. [2006] продемонстрировали, что генерация активных форм кислорода, НАДФ-Н оксидазой эндофита Epichloë festucae, необходима для инактивации защитных реакций растений-хозяев. Поскольку активные формы кислорода играют роль в запрограммированной гибели клеток, общих реакциях на стресс и системной передаче сигналов, они могут оказывать большое влияние на эффективность инфекции и колонизации внутренних тканей растений. Однако, окислительный взрыв в растениях является одной из наиболее ранних реакций на воздействие патогенных микроорганизмов. Поэтому важным является вопрос о механизмах, позволяющих эндофитным бактериям успешно колонизировать ткани хозяев, не вызывая иммунной реакции растения на их инвазию.

\section{МАТЕРИАЛЫ И МЕТОДЫ}

В работе использованы пробирочные стерильные растения картофеля (Solanum tuberosum L.) сорта Ранняя роза, культивируемые в течение 25 сут при 16 часовой освещенности 12-16 тыс. люкс (лампы Osram L 36W/77, Германия), в климатокамере КС200 (“Смоленский СКТБ СПУ”, Россия) на агаризованной среде Муросиге-Скуга. Инокулировали суспензией бактерий (105л/мл) нанесением по 3 мкл на 5 верхних листьев. Использовали штаммы B. subtilis 26Д (синтезирующий сурфактин), полученные на его основе линии B. subtilis $\mathrm{Sn}$ и B. subtilis SFP с нарушенным синтезом сурфактина, штамм $B$. subtilis 11BМ продуцирующий итурин. Через 15, 30, 45, 60 минут по 3 растения на каждый вариант фиксировали для биохимических анализов и через 7 суток подсчитывали число колониеобразующих единиц (КОЕ). Для этого 200 мг навески растительного материала стерилизовали 3 мин. в 96\% спирте, дважды промывали стерильной водой по 2 мин., подсушивали на фильтровальной бумаге и растирали в фарфоровой ступке с 2 мл стерильной воды, затем разбавляли в 20 раз и 50 мкл разбавленной смеси наносили на твердую сухую поверхность агаризованной среды в чашке Петри диаметром 60 мм, и растирали шпателем Дригальского до полного высыхания. Инкубировали 24 часа при 27С, затем подсчитывали число колониеобразующих единиц (КОЕ/мг сырой массы).

Навеску пробирочныхрастений растирали в $0.025 \mathrm{M}$ фосфатном буфере(ФБ) рН 6.2 в соотношении $1: 5$, экстрагировали 30 мин при $4^{\circ} \mathrm{C}$, затем центрифугировали 10 мин при 8000 $\mathrm{g}$ на микроцентрифуге Eppendorf 5415R (США). Активность пероксидазы измеряли микрометодом с использованием орто-фенилендиамина в качестве субстрата. Концентрацию перекиси водорода измеряли с использованием красителя ксиленоловый оранжевый [Sorokan et al., 2018]. 
В работе анализировали биоматериал каждого из трех повторов одного варианта опыта. Статистическая обработка проводилась компьютерными программами фирмы Stat Soft (Statistica 6.0).

\section{РЕЗУЛЬТАТЫ}

Через 7 дней после инокуляции исследуемыми штаммами растений картофеля сорта Ранняя Роза, было показано, что наиболее высокой способностью проникать во внутренние ткани растений обладал продуцирующий сурфактин штамм B.subtilis 26Д (таблица 1). Клеток рекомбинантного штамма, не продуцирующего сурфактин B. subtilis $\mathrm{Sn}$ и продуцирующего итурин $B$. subtilis 11 ВМ во внутренних тканях растений содержалось в 4 раза меньше, чем В. subtilis 26Д. Штамм B. subtilis SFP проникал во внутренние ткани растений в большей степени, чем другие безсурфактиновые штаммы, но вдвое меньше, чем исходный штамм. Интересно, что предварительная обработка растений экзогенной перекисью водорода так же снижала содержание бактерий $B$. subtilis 26 д во внутренних тканях растений.

Таблица 1. Исследование содержания бактерий рода Bacillus во внутренних тканях растений.

\begin{tabular}{l|c}
\hline Название штамма & КОЕ/ мг сырой массы \\
\hline B. subtilis 26Д & 20830,34 \\
B. subtilis Sn & 5260 \\
B. subtilis $\mathbf{1 1}$ ВM & 4930,34 \\
Н2 $_{2}+$ B. subtilis 26Д & 6880,67 \\
B. subtilis SFP & 9360,34 \\
\hline
\end{tabular}

Как видно из рис. 1, в растениях картофеля, инокулированных суспензией клеток $B$. subtilis Sn и B. subtilis SFP, происходило повышение концентрации перекиси водорода во всех временных точках. Также образованию высокой концентрации перекиси водорода способствовала инокуляция штаммом B. subtilis 11ВМ. Важно, что инокуляция B. subtilis 26Д практически не влияла на содержание перекиси водорода в растениях.

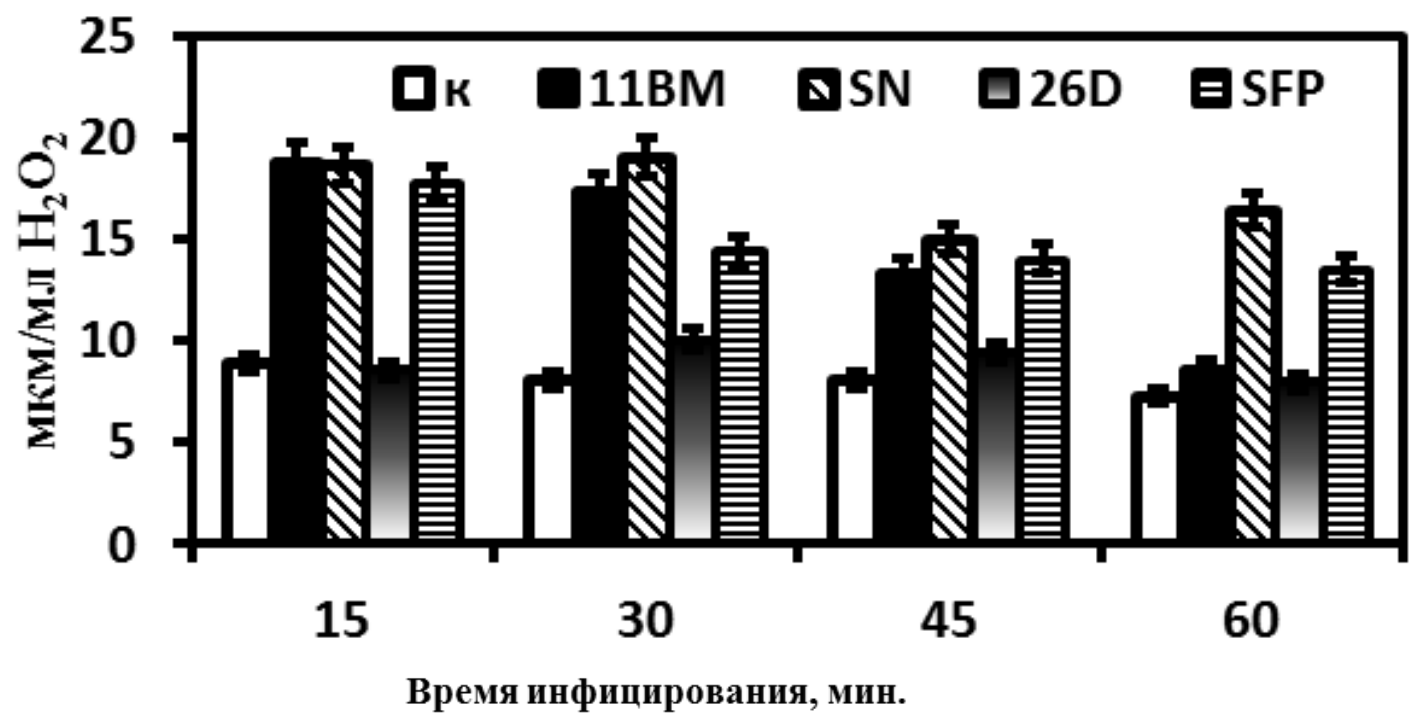

Рис. 1 Влияние B.subtilis 26Д, Sn, SFP, 11BM на концентрацию перекиси водорода в растениях картофеля при инокуляции суспензией бактерий $\left(10^{5}\right.$ кл/мл). 
Наиболее высокую способность повышать активность каталазы, важнейшего фермента утилизации перекиси водорода, в листьях картофеля имели штаммы B. subtilis 11ВМ и B. subtilis 26Д через 15 минут после инокуляции. Вероятно, в случае штамма 26Д это привело к снижению содержания перекиси водорода. В последующем активность каталазы в обработанных штаммом 11 ВМ растениях находится на контрольном уровне, в остальных вариантах обработок - ниже контрольного. Также через 60 мин фиксации наблюдается повышение активности каталазы благодаря обработке штаммом B.subtilis SFP. Пероксидазная активность возрастала по отношению к контрольным показателям в случае обработки растений суспензией штамма B. subtilis 11BM, продуцирующего итурин.

Таким образом, штамм B.subtilis 26Д, в высоком количестве проникающий во внутренние ткани растений, на начальных этапах взаимодействия с растением не вызывает накопления перекиси водорода, как это наблюдается при обработке штаммами не продуцирующими сурфактин. Принимая во внимание снижение содержания живых клеток $B$. subtilis 26Д в растениях, обработанных перекисью водорода перед инокуляцией, можно сделать вывод о важности сурфактина в регуляции взаимодействия бактерий с растением.

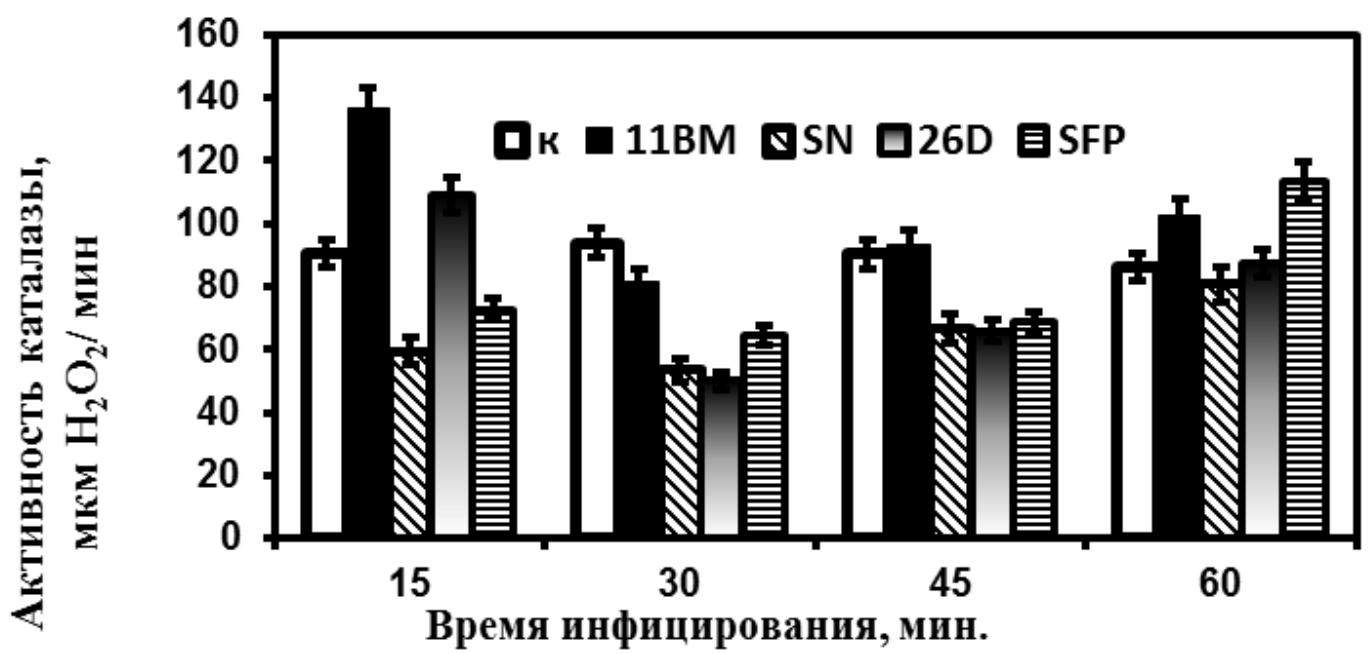

Рис. 2 Влияние B.subtilis 26Д, Sn, SFP, 11BM на активность каталазы (мкмН $\mathrm{O}_{2}$ / мг белка* мин) в растениях картофеля при инокуляции суспензией бактерий $\left(10^{5}\right.$ кл/мл)

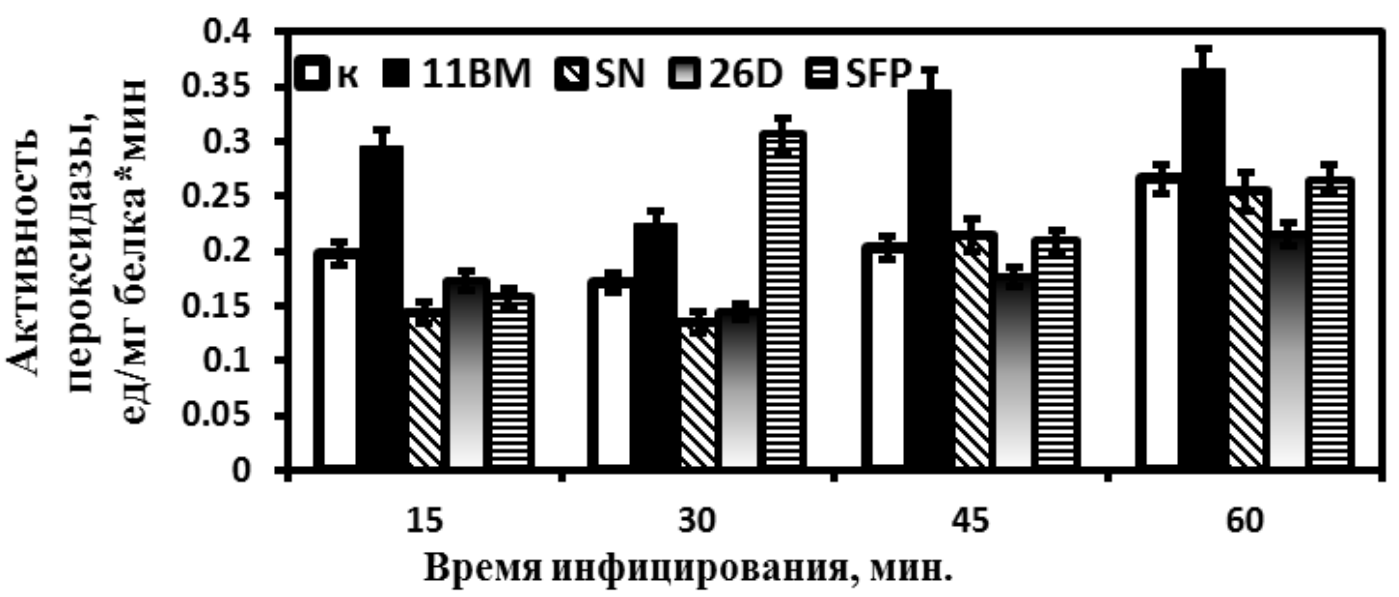

Рис. 3. Влияние B. subtilis 11BM, Sn, 26Д, SFP на активность пероксидазы (ед/мг белка* мин) в растениях картофеля при инокуляции суспензией бактерий (105л/мл). 


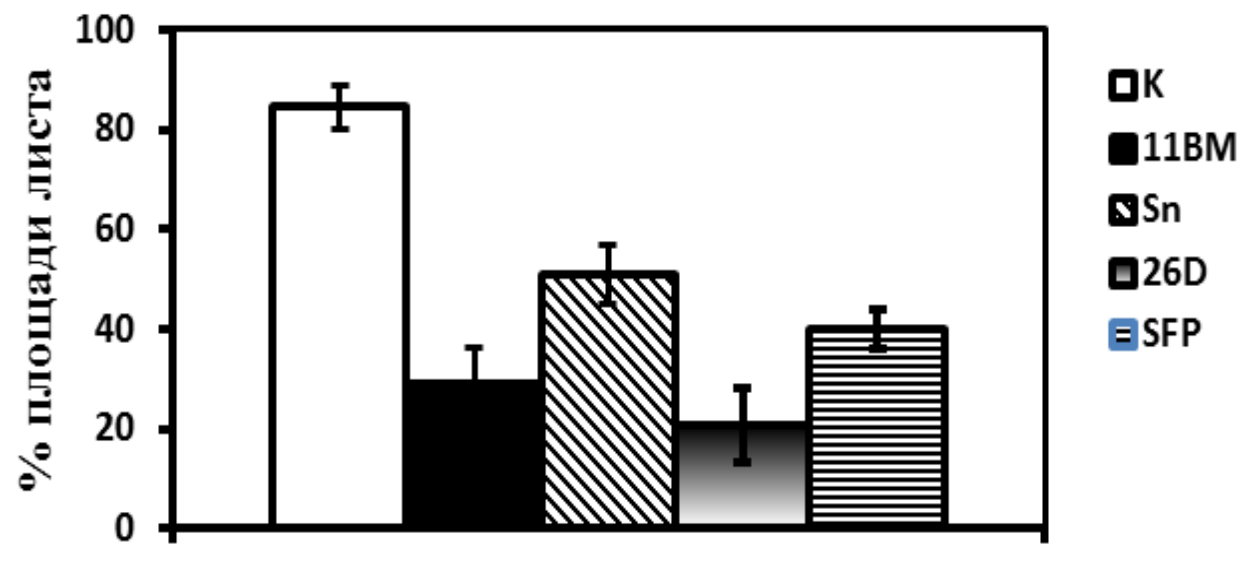

Рис. 4 Влияние бактерий B. subtilis 11BM,Sn, 26Д на развитие симптомов фитофтороза на листьях растений картофеля на 10 сутки после инфицирования P.infestans

Из рис. 4. видно, что наиболее эффективным штаммом, снижающим развитие симптомов фитофтороза на листьях растений картофеля, являются B. subtilis 26Д и B. subtilis 11 ВМ. Пониженное содержание эндофитов B. subtilis $\mathrm{Sn}$ и B. subtilis SFP, которые не продуцировали сурфактин, приводила к увеличению восприимчивости растений к возбудителю фитофтороза по отношению к исходному штамму. Таким образом, продукция сурфактина обусловливает эффективную колонизацию растений картофеля бактериями $B$. subtilis 26Д, что существенно увеличивает их устойчивость к возбудителю фитофтороза.

Работа выполнена в рамках Госзадания № 116020350027-7 (2016-2018) при частичной финансовой поддержке РФФИ 17-29-08014 офи_м и РФФИ18-34-00021 мол_а.

\section{СПИСОК ЛИТЕРАТУРЫ}

1. Сидорова Т.М., Асатурова А.М., Хомяк А.И.. Биологически активные метаболиты Bacillus subtilis и их роль в контроле фитопатогенных микроорганизмов (обзор) // Сельскохозяйственная биология. 2018. T. 53. № 1. С. 29-38. DOI: 10.15389/agrobiology.2018.1.29rus

2. Чеботарь В.К., Щербаков А.В., Масленникова С.Н, Заплаткин А.Н., Канарский А.В., Завалин А.А. Эндофитные бактерии как основа комплексных микробных препаратов для сельского и лесного хозяйства // Агрохимия. 2016. №11. С.65-70.

3. Goswami M., Deka S. Biosurfactant production by a rhizosphere bacteria Bacillus altitudinis MS16 and its promising emulsification and antifungal activity // Colloids Surf B Biointerfaces. 2019. V. 178. P. 285-296. DOI: 10.1016/j.colsurfb.2019.03.003

4. Martinez-Medina A., Flors V., Heil M., Mauch-Mani B., Pieterse C.M., Pozo M.J. Recognizing plant defense priming. Trends Plant Sci. 2016. V. 21. P. 818-822. DOI: $10.1016 /$ j.tplants.2016.07.009

5. Sorokan A.V., Burhanova G.F., Maksimov I.V. Anionic peroxidase-mediated oxidative burst is required for jasmonic acid-dependent Solanum tuberosum L. defense against Phytophthora infestans (Mont) de Bary // Plant Pathology. 2018. V 67. P. 349-357 DOI: 10.1111/ppa.12743

6. Spaepen S, Vanderleyden J, Remans R. Indole-3-acetic acid in microbial and microorganismplant signaling // FEMS Microbiol Rev. 2007. V. 31. P. 425-48. DOI: 10.1111/j.15746976.2007.00072.x

7. Stringlis I.A., Proietti S., Hickman R., Van Verk M. C., Zamioudis C., Pieterse C. M. J. Root transcriptional dynamics induced by beneficial rhizobacteria and microbial immune elicitors reveal signatures of adaptation to mutualists // Plant J. 2018. V. 15. P. 166-180. DOI: $10.1111 /$ tpj.13741

8. Tanaka A., Christensen M.J., Takemoto D., Pyoyun P., Scott B. Reactive oxygen species play a role in regulating a fungus-perennial ryegrass mutualistic interaction // Plant Cell. 2006. V. 18. P. 1052-1066. DOI: 10.1105\%2Ftpc.105.039263 